\title{
Production of biohydrogen by recombinant expression of [NiFe]-hydrogenase 1 in Escherichia coli
}

Jaoon YH Kim¹, Byung Hoon Jo² and Hyung Joon Cha*1,2

\begin{abstract}
Background: Hydrogenases catalyze reversible reaction between hydrogen $\left(\mathrm{H}_{2}\right)$ and proton. Inactivation of hydrogenase by exposure to oxygen is a critical limitation in biohydrogen production since strict anaerobic conditions are required. While [FeFe]-hydrogenases are irreversibly inactivated by oxygen, it was known that [NiFe]-hydrogenases are generally more tolerant to oxygen. The physiological function of [NiFe]-hydrogenase 1 is still ambiguous. We herein investigated the $\mathrm{H}_{2}$ production potential of [NiFe]-hydrogenase 1 of Escherichia coli in vivo and in vitro. The hyaA and hyaB genes corresponding to the small and large subunits of [NiFe]-hydrogenase 1 core enzyme, respectively, were expressed in BL21, an E. coli strain without $\mathrm{H}_{2}$ producing ability.
\end{abstract}

Results: Recombinant BL21 expressing [NiFe]-hydrogenase 1 actively produced $\mathrm{H}_{2}(12.5 \mathrm{~mL} \mathrm{H} /(\mathrm{h} \cdot \mathrm{L})$ in $400 \mathrm{~mL}$ glucose minimal medium under micro-aerobic condition, whereas the wild type BL21 did not produce $\mathrm{H}_{2}$ even when formate was added as substrate for formate hydrogenlyase (FHL) pathway. The majority of recombinant protein was produced as an insoluble form, with translocation of a small fraction to the membrane. However, the membrane fraction displayed high activity ( $65 \%$ of total cell fraction), based on unit protein mass. Supplement of nickel and iron to media showed these metals contribute essentially to the function of [NiFe]-hydrogenase 1 as components of catalytic site. In addition, purified E. coli [NiFe]-hydrogenase 1 using his ${ }_{6}$-tag displayed oxygen-tolerant activity of $\sim 12 \mathrm{nmol} \mathrm{H} / /(\mathrm{min} \cdot \mathrm{mg}$ protein) under a normal aeration environment, compared to [FeFe]-hydrogenase, which remains inactive under this condition.

Conclusions: This is the first report on physiological function of $E$. coli [NiFe]-hydrogenase 1 for $\mathrm{H}_{2}$ production. We found that [NiFe]-hydrogenase 1 has $\mathrm{H}_{2}$ production ability even under the existence of oxygen. This oxygen-tolerant property is a significant advantage because it is not necessary to protect the $\mathrm{H}_{2}$ production process from oxygen. Therefore, we propose that [NiFe]-hydrogenase can be successfully applied as an efficient biohydrogen production tool under micro-aerobic conditions.

\section{Background}

Hydrogenases have been identified in many archaea and bacteria since the initial discovery of the enzyme in Escherichia coli [1]. These proteins play important roles in energy metabolism by catalyzing the reversible reaction between hydrogen $\left(\mathrm{H}_{2}\right)$ and proton. Hydrogenases are divided into three classes based on metal content, specifically, [FeFe]-hydrogenases (previously known as

* Correspondence: hjcha@postech.ac.kr

1 Department of Chemical Engineering, Pohang University of Science and Technology, Pohang 790-784, Korea

Full list of author information is available at the end of the article
[Fe]-hydrogenase), [NiFe]-hydrogenases, and metal-free hydrogenases (now known as [Fe]-hydrogenase) [2]. Among these classes, [FeFe]- and [NiFe]-hydrogenases are the major enzymes; most of hydrogenases found in microorganisms are belong to one of these two enzymes except metal-free hydrogenases that were discovered in some methanogens. The mostly monomeric [FeFe]hydrogenases are more involved in $\mathrm{H}_{2}$ evolution, and display high sensitivity to oxygen $\left(\mathrm{O}_{2}\right)$ and carbon monoxide (CO) (irreversibly inactivated after exposure to $\mathrm{O}_{2}$ ) [3,4]. [NiFe]-hydrogenases, composed of two subunits, are 
involved in $\mathrm{H}_{2}$ oxidation, but also catalyze reversible reactions $[5,6]$. These enzymes are less active than $[\mathrm{FeFe}]-$ hydrogenases by $10 \sim 10^{2}$ fold, but much more tolerant to $\mathrm{O}_{2}$ or $\mathrm{CO}$ in a reversible manner [4]. This property is a significant advantage for the biotechnological application of hydrogenase in biohydrogen production, since it is not necessary to protect the production process from $\mathrm{O}_{2}$.

Several types of [NiFe]-hydrogenases have been isolated and characterized using genetic and biochemical methods $[2,7,8]$ following the discovery of the enzyme in Methanobacterium thermoautotrophicum [9]. In E. coli, four types of [NiFe]-hydrogenases have been isolated, and their roles extensively analyzed [10]. Hydrogenase 3 (encoded by hyc operon, group 4 [2]) participates in $\mathrm{H}_{2}$ production as part of the formate hydrogenlyase (FHL) complex. The FHL complex couples formate oxidation by formate dehydrogenase $\mathrm{H}$ (FDH-H) with proton reduction by hydrogenase 3. FDH and hydrogenase 3 are expressed only under strictly anaerobic conditions, and have a highly oxygen-labile nature [2,11]. Accordingly, their application in biohydrogen production using formate as a substrate in anaerobic $E$. coli fermentation has been extensively studied [12]. Hydrogenases 1 and 2 (encoded by hya and hyb operons, respectively, group 1 [2]) in E. coli were isolated by several groups during the mid 1980s [11,13-16]. Results from genetic and physiological studies indicate that hydrogenase 2 is responsible for uptake of $\mathrm{H}_{2}$ as an electron donor during anaerobic respiration, with fumarate serving as an electron acceptor or glycerol. This allows cells to obtain energy from $\mathrm{H}_{2}$ oxidation $[11,13]$.

The physiological role of hydrogenase 1 is still a matter of dispute. It was reported that active hydrogenase 1 and 2 are produced in E. coli during late exponential to early stationary phases when $\mathrm{H}_{2}$ concentration would be saturated and hydrogenase 1 could have a role for $\mathrm{H}_{2}$ oxidation [14]. Hydrogenase 1 was suggested to participate in recycling of $\mathrm{H}_{2}$ produced by hydrogenase 3 [16]. It was also concluded that hydrogenase 1 is not a part of $\mathrm{H}_{2}$ evolving FHL system and its role is unclear even though formate is required for expression of hydrogenase 1 [16]. A number of studies have shown that the $\mathrm{H}_{2}$-producing ability of a hydrogenase 3 knockout mutant is weak and negligible, leading to the conclusion that hydrogenase 1 only performs $\mathrm{H}_{2}$ uptake [17]. In contrast to this conclusion, mutation of hydrogenase 1 did not improve or reduce $\mathrm{H}_{2}$ production $[17,18]$ whereas deletion of hydrogenase 2 wholly contributed to increased $\mathrm{H}_{2}$ production $[13,18]$. Hydrogenase 1 and 2 are also immunologically distinct to each other [16]. Thus, it is inaccurate to assume that hydrogenase 1 only exhibits $\mathrm{H}_{2}$ uptake activity, similar to hydrogenase 2 . In general, the physiological function of hydrogenase 1 is ambiguous [14,18-22].
Hydrogenases, including E. coli hydrogenase 1, are uniquely grouped (group 1) based on conserved sequences in their small and large subunits [2]. Using this property, we previously obtained genes for group 1 [NiFe]-hydrogenase core enzyme [23]. Expression of $E$. coli hydrogenase 1 is $\mathrm{pH}$-dependent [19,24], and the enzyme displays a high ratio of $\mathrm{H}_{2}$ evolution/ $\mathrm{H}_{2}$ oxidation for methyl viologen (MV) as substrate under acidic conditions [5,14], similar to another hydrogenase belonging to this group [6]. This finding implies that its reversible reaction is dependent on cellular physiology and possible action as a $\mathrm{H}_{2}$-producing enzyme, dependent on the conditions. The enzyme is stable over a wide range of $\mathrm{pH}$ values $[13,16]$ and more tolerant to $\mathrm{O}_{2}$, compared to hydrogenase 2, FHL, and [FeFe]-hydrogenase $[4,14,25$ 27].

In the present work, we investigated $\mathrm{H}_{2}$ production ability of homologously expressed $E$. coli [NiFe]-hydrogenase 1 as a model of group 1 hydrogenase at in vivo and in vitro status. Through the study, we also try to reveal the basic property of recombinant [NiFe]-hydrogenase 1 related to metabolism, metal effect, and oxygen-tolerance with focusing on $\mathrm{H}_{2}$ production.

\section{Results}

$\mathrm{H}_{2}$ production in E. coli BL21 by homologous expression of E. coli hydrogenase 1

Hydrogenase 1 of $E$. coli is transcribed from the hya operon composed of six genes (hyaABCDEF) [15]. Among these, hya $\mathrm{A}$ and hya $\mathrm{B}$ encode the small and large core enzyme subunits, respectively. For expression of hydrogenase 1 , the full hya operon was initially amplified from the E. coli $\mathrm{K} 12$ genome, and genes for these core enzyme subunits (hyaA and hyaB) cloned under control of the T7lac promoter (pET-EcHAB vector; Fig. 1B). E. coli BL21 was used as the host strain to overexpress recombinant hydrogenase 1 for investigation of $\mathrm{H}_{2}$ production, since this strain does not have ability to generate $\mathrm{H}_{2}$ [25,28]. As expected, wild-type BL21 containing the parent pET-21b vector did not produce any $\mathrm{H}_{2}$ gas whereas the recombinant strain overexpressing hya $\mathrm{A}$ and hya $\mathrm{B}$ actively produced $\mathrm{H}_{2}$ in $100 \mathrm{~mL}$ culture in a $125 \mathrm{~mL}$ serum bottle (bars (a) vs (b), Fig. 2). As a comparative study, complete hya operon was also overexpressed in $E$. coli BL21. However, we observed no differences from the strain overexpressing hya $\mathrm{A}$ and hya $\mathrm{B}$ only (data not shown).

\section{Effect of endogenous or exogenous Formate on $\mathrm{H}_{2}$ production by recombinant $E$. coli hydrogenase 1}

Next, we investigated whether $\mathrm{H}_{2}$ production by hydrogenase 1 is related to endogenous or exogenous formate and FHL in E. coli. $\mathrm{H}_{2}$ production in several Enterobacteriacae, including $E$. coli, mainly relies on the FHL pathway 


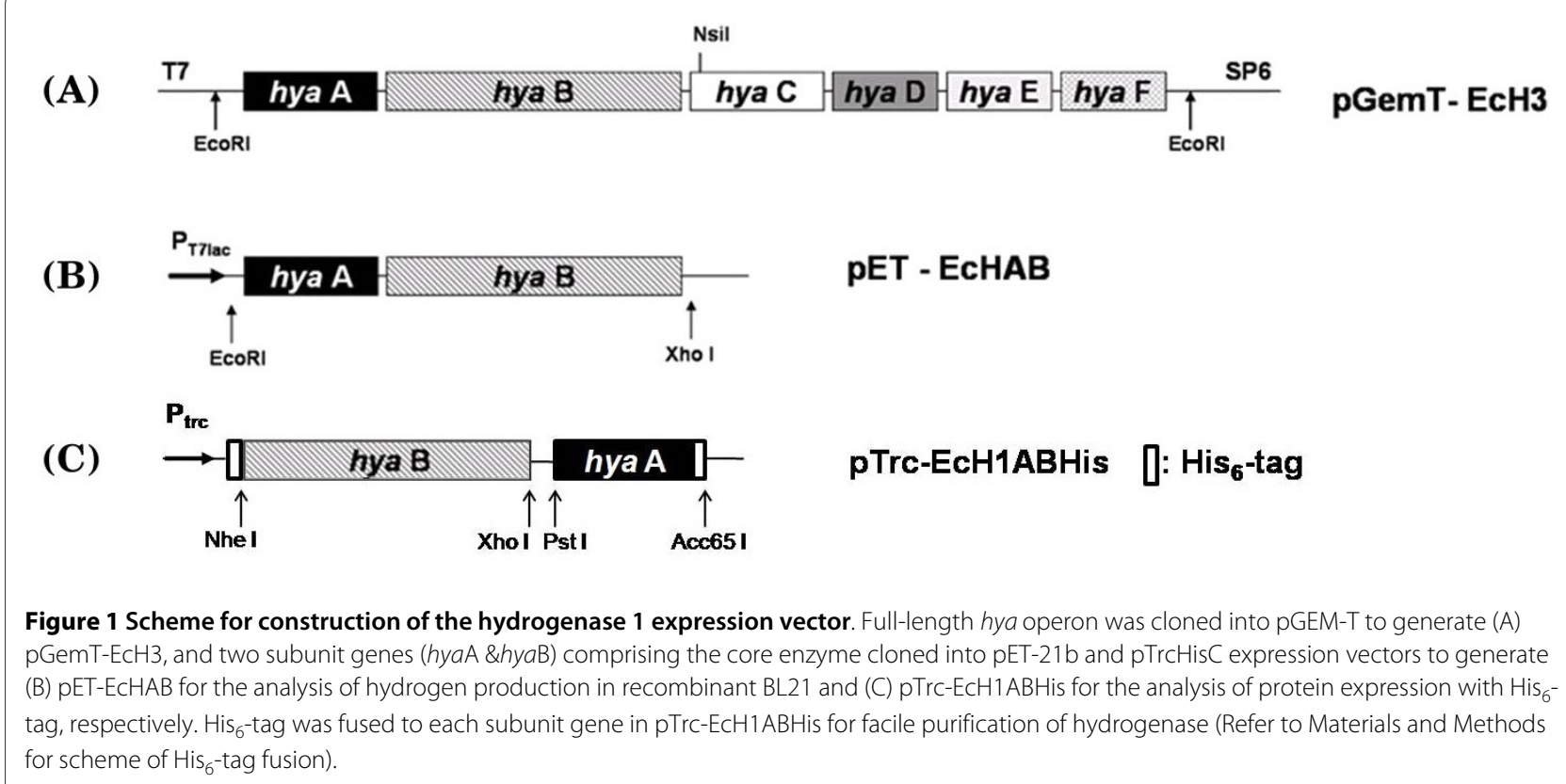

pTrc-EcH1ABHis []: $\mathrm{His}_{6}$-tag

Figure 1 Scheme for construction of the hydrogenase 1 expression vector. Full-length hya operon was cloned into pGEM-T to generate (A) pGemT-ECH3, and two subunit genes (hyaA \&hyaB) comprising the core enzyme cloned into pET-21b and pTrcHis C expression vectors to generate (B) pET-ECHAB for the analysis of hydrogen production in recombinant BL21 and (C) pTrc-EcH1 ABHis for the analysis of protein expression with His ${ }_{6}-$ tag, respectively. His 6 -tag was fused to each subunit gene in pTrc-EcH1ABHis for facile purification of hydrogenase (Refer to Materials and Methods for scheme of $\mathrm{His}_{6}$-tag fusion).

[29]. Formate is produced via pyruvate formate lyase (PFL) from pyruvate under anaerobic conditions. Endogenous formate is decomposed into carbon dioxide $\left(\mathrm{CO}_{2}\right)$ and proton by formate dehydrogenase (FDH-H), and $\mathrm{H}_{2}$ generated from the proton by hydrogenase 3 in $E$. coli. We investigated the effect of exogenous formate by adding $10 \mathrm{mM}$ formate to the medium. $\mathrm{H}_{2}$ production increased more than 2-fold in BL21 cells with recombinant hydrogenase 1 , compared to that in cultures not exposed to formate (bars (e) vs (b), Fig. 2). However, wildtype BL21 did not produce $\mathrm{H}_{2}$, regardless of addition of $10 \mathrm{mM}$ formate (bars (b) \& (d), Fig. 2). This result implies that FHL system of wild type BL21 was impaired. Moreover, since formate is produced from pyruvate, we analyzed the effects of glucose on $\mathrm{H}_{2}$ production. The glucose concentration did not affect the $\mathrm{H}_{2}$ production to a notable extent. Specifically, we did not observe any noticeable increase in $\mathrm{H}_{2}$ production with an increment in glucose concentration from $0.5 \%$ to $1.5 \%(\mathrm{w} / \mathrm{v})$ (data not shown). In addition, we analyzed the effect of endogenous formate on $\mathrm{H}_{2}$ production by recombinant hydrogenase 1 using sodium hypophosphite, an inhibitor of PFL. Interestingly, BL21 expressing recombinant hydrogenase 1 did not produce detectable $\mathrm{H}_{2}$ following the addition of $10 \mathrm{mM}$ sodium hypophosphite (bar (c), Fig. 2).

\section{Enzymatic activity and localization of recombinant $E$. coli hydrogenase 1}

To assess whether expression of recombinant hydrogenase 1 results in a functional enzyme, we assayed enzy- matic activity in relation to metal content. We initially investigated metal effects on $\mathrm{H}_{2}$ production in vivo by altering the ratios of nickel and iron (Fig. 3A). As $\mathrm{H}_{2}$ production showed saturated patterns over $20 \mu \mathrm{M}$ nickel and iron (data not shown), we set each metal concentration as $30 \mu \mathrm{M}$ in subsequent experiments. Additionally, we used minimal medium, M9CA (M9 media supplemented with casamino acid), to minimize the effects of residual metals on $\mathrm{H}_{2}$ production in vivo and in vitro. Actually, in LB medium, we observed recombinant BL21 produce hydrogen even without addition of $\mathrm{Ni}$ and $\mathrm{Fe}$, but there were significant variations according to each culture (data not shown) and it was not so reliable. Upon $400 \mathrm{~mL}$ culture in a $500 \mathrm{~mL}$ serum bottle in the presence of $30 \mu \mathrm{M}$ both nickel and iron, recombinant BL21 generated $\mathrm{H}_{2}$ most actively $(\sim 80 \mathrm{~mL})$ at $16 \mathrm{~h}$ post-induction, with productivity of $12.5 \mathrm{~mL} \mathrm{H}_{2} /\left(\mathrm{h} \cdot \mathrm{L}\right.$ ) (Fig. $3 \mathrm{~A}$ ). Interestingly, $\mathrm{H}_{2}$ was generated $(\sim 17 \mathrm{~mL})$ with low productivity of $2.7 \mathrm{~mL} \mathrm{H}_{2}$ / $(\mathrm{h} \cdot \mathrm{L})$ culture, in the presence of $30 \mu \mathrm{M}$ iron only. However, upon the addition of $30 \mu \mathrm{M}$ nickel only, recombinant $E$. coli produced very low amounts of $\mathrm{H}_{2}$, and no detectable $\mathrm{H}_{2}$ was produced with no addition of both metals. Assessment of the metal content of minimal M9CA medium using atomic absorption spectrometry revealed no $\mathrm{Ni}$ and $\mathrm{Fe}$ at the detection limit of $0.05 \mathrm{ppm}$ (corresponding to $0.85 \mu \mathrm{M} \mathrm{Ni}$ and $0.89 \mu \mathrm{M} \mathrm{Fe}$ ).

To assay the biological activity of recombinant enzyme, we separated the sample into total cell lysate, cell debris, crude extract, cytosolic, and membrane fractions. Comparable to in vivo $\mathrm{H}_{2}$ production, samples from each culture showed similar hydrogenase activities of in vitro $\mathrm{H}_{2}$ 


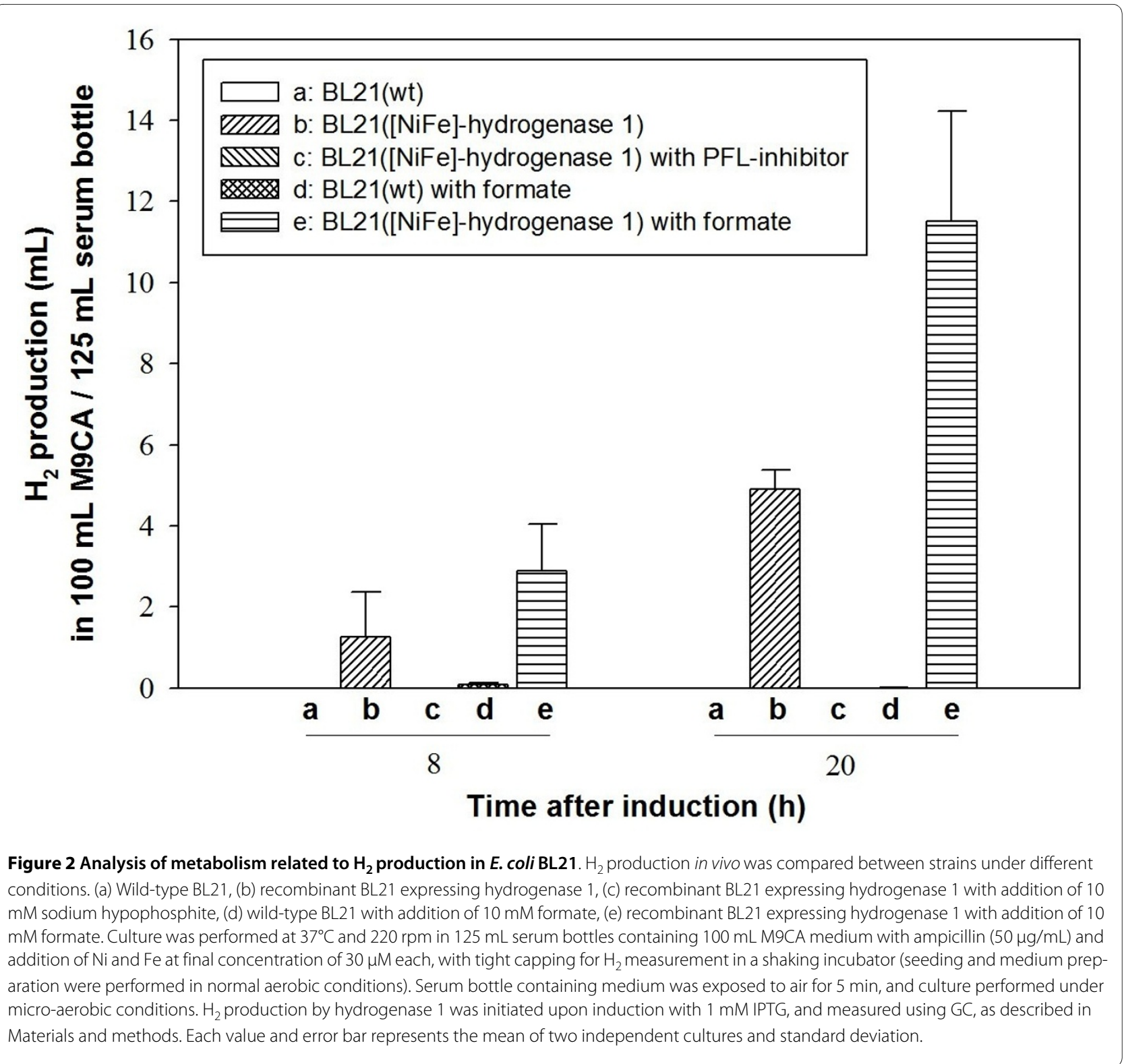

evolution in both total cell lysate and membrane fractions (Fig. 3B). Total cell lysate and membrane fractions displayed the highest activities $\left(\sim 38\right.$ and $\sim 25 \mathrm{nmol} \mathrm{H}_{2} /$ (min.mg protein), respectively) when supplemented with both nickel and iron. Upon the addition of iron only to the medium, enzyme activities remained at about $9.4 \%$ (total cell lysate fraction) and 20\% (membrane fraction) of those observed in the presence of both metals. In the case of nickel only, activities of $4.7 \%$ and $7.4 \%$ were estimated for the total cell lysate and membrane fractions, respectively. No hydrogenase activity was evident in samples prepared without metals. Importantly, the membrane fraction showed relatively high (about 65\% with both $\mathrm{Ni}$ \& Fe) activity per unit mass of total protein compared to the total cell lysate. However, the activity levels of crude extract (substraction of cell debris from the total cell lysate) and cytosolic (substration of crude membrane from crude extract) fractions were significantly lower than those of total cell lysate and membrane fractions (data not shown). Note that we prepared all protein samples for enzyme assay under normal aerobic conditions during harvesting, disruption, and ultracentrifugation. Since the FHL system is easily inactivated under aerobic conditions [11], the $\mathrm{H}_{2}$ evolving activity of the cellular extract in the presence of oxygen implies that recombinant $E$. coli hydrogenase 1 displays $\mathrm{O}_{2}$-tolerant $\mathrm{H}_{2}$-evolving activity.

[NiFe]-hydrogenase group 1 follows the twin-argininetranslocation (Tat) pathway [2], and localizes to the periplasmic space after maturation and complex forma- 

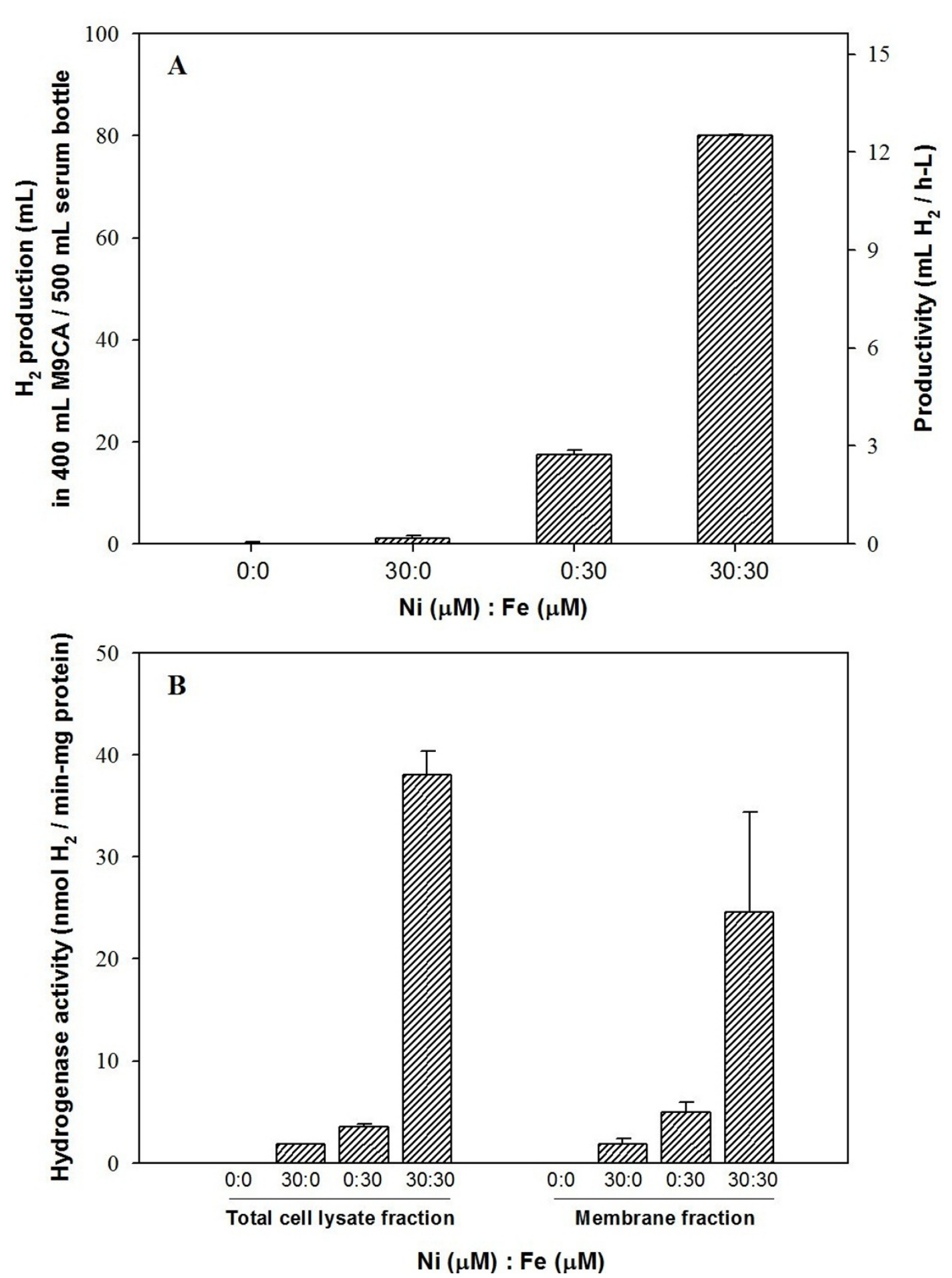

Figure 3 (A) In vivo $\mathrm{H}_{2}$ production according to metal content and (B) in vitro hydrogenase 1 activity according to metal content and cellular fraction. Culture was performed in $500 \mathrm{~mL}$ serum bottles containing $400 \mathrm{~mL}$ M9CA medium. The metal composition was set as four combinations, specifically, (Ni $0 \mu \mathrm{M}, \mathrm{Fe} 0 \mu \mathrm{M})$, (Ni $30 \mu \mathrm{M}$, Fe $0 \mu \mathrm{M})$, (Ni $0 \mu \mathrm{M}$, Fe $30 \mu \mathrm{M})$, (Ni $30 \mu \mathrm{M}$, Fe $30 \mu \mathrm{M})$. Cell fractionation was performed as described in Materials and methods. Other conditions were similar to those described for Fig. 2. Each value and error bar represents the mean of triplicate samples and standard deviation. 
tion. Accordingly, we investigated the cellular localization of recombinant hydrogenase 1 of $E$. coli under similar conditions used for analysis of enzyme activity. Total cell lysate, insoluble cell debris, crude extract, and membrane fractions from each culture sample were isolated and analyzed by Western blotting using anti-His ${ }_{6}$ antibody. Large $(\sim 68 \mathrm{kDa})$ and small $(\sim 40 \mathrm{kDa})$ subunits of hydrogenase 1 were overexpressed in the total cell lysate fraction (lane $\mathrm{T}$, Fig. 4). However, the majority of protein was produced as inclusion bodies detected in the insoluble cell debris fraction (lane IS, Fig. 4), and a very small amount of hydrogenase was expressed as the soluble form in the crude extract fraction (lane S, Fig. 4). A significantly low level of hydrogenase 1 was successfully translocated to the membrane and it was detectable after the soluble crude extract fraction was concentrated to 25 -fold concentration by ultracentrifugation (lane M, Fig. 4). We observed no significant changes in protein expression upon alteration of the metal content.

In addition, recombinant $E$. coli hydrogenase 1 was purified (data not shown) in the normal aerobic environment using immobilized metal affinity chromatography with the $\mathrm{His}_{6}$-tag fused to each subunit (pTrcEch1ABHis; Fig. 1C). Hydrogenase evolution activity data showed that purified $\mathrm{His}_{6}$-tag fused recombinant [NiFe]hydrogenase 1 produced $\sim 12$ nmole $\mathrm{H}_{2} /$ (min.mg protein). Notably, enzymatic activity of [FeFe]-hydrogenase was not detected under same aerobic conditions [25].

\section{Discussion}

A previous trial in 1979 demonstrated that purified E. coli hydrogenase from aerobic culture could tolerate an aerobic atmosphere with a half-life of $12 \mathrm{~h}$ [5]. This hydrogenase was later identified as isoenzyme 1 by immunoblotting after isolation of three types of $E$. coli hydrogenase [14]. A study on E. coli hydrogenase 1 expression was performed to determine the roles of proteins comprising the hya operon in a hya mutant strain [15]. However, due to remaining hydrogenase activities in the hya mutant, it was difficult to ascertain the role of hydrogenase 1, and research studies were focused on its $\mathrm{H}_{2}$ uptake property. Subsequently, several studies have been performed on hydrogenase 1 in E. coli [14,18-22]. Hydrogenase 1 was induced under anaerobic conditions similar to other isoenzymes, but its regulation was distinct from that of hydrogenases 2 and 3 [22]. The enzyme was also induced by formate, similar to FHL, but responded differently to the global regulatory mechanism related to $f n r$. Moreover, hydrogenase 1 had biochemical properties similar to those of hydrogenase 2, but was not immunogenically cross-reactive with hydrogenase 2 $[21,22]$. The enzyme reversibly catalyzed both dihydrogen evolution and uptake [5,14]. However, a majority of studies concluded that it is not clear to define the physiological role of hydrogenase 1 in E. coli or whether it has similar property to hydrogenase 2 or not. Recent reports have shown that $\mathrm{H}_{2}$ production was enhanced in deletion mutants of hya $\mathrm{B}$ and $h y b \mathrm{C}$ (encoding the large subunit of hydrogenase 2), leading to the proposal that both E. coli hydrogenases 1 and 2 have $\mathrm{H}_{2}$ uptake activity [17]. However, it remains to be revealed whether $\mathrm{H}_{2}$ production is enhanced due to mutation of both hydrogenases or hydrogenase 2 only because another report on this issue suggested that enhancement of $\mathrm{H}_{2}$ production is entirely dependent on mutation of hydrogenase 2 , but not hydrogenase 1 [18].

In the present work, we investigated the potential of [NiFe]-hydrogenase group 1 as a $\mathrm{H}_{2}$-producing enzyme under micro-aerobic conditions using $E$. coli hydrogenase 1 as a model. Although we cloned only the two subunits (small and large subunits) comprising core enzyme of hydrogenase 1, recombinant BL21 successfully produced hydrogen. Large subunit has catalytic site for conversion from hydrogen to proton and electron, and vice versa. Small subunit has [Fe-S] clusters for the transfer of electrons to catalytic site in large subunit. It has been known that accessory proteins are also required for the function of mature [NiFe] hydrogenase 1 [15]. We surmise that there was basal expression of native accessory proteins in the host strain that is required for the assembly and function of E. coli hydrogenase 1, and these proteins also functioned on recombinant hydrogenase 1 . We initially examined the basic properties of the enzyme in relation to $\mathrm{H}_{2}$ metabolism in E. coli. Similar to other enterobacteria, E. coli utilizes mainly FHL pathway to produce $\mathrm{H}_{2}$ from formate, a product of the PFL pathway. Under the addition of formate, $\mathrm{H}_{2}$ production increased more than 2-fold in BL21 cells with recombinant hydrogenase 1, compared to the culture without formate (bars (e) $v s$ (b), Fig. 2). However, wild-type BL21 did not produce $\mathrm{H}_{2}$, regardless of addition of $10 \mathrm{mM}$ formate (bars (a) \& (d), Fig. 2) even if formate is known as substrate for FHL complex to produce hydrogen. We also investigated the effect of endogenous formate on $\mathrm{H}_{2}$ production by recombinant hydrogenase 1 using sodium hypophosphite, an inhibitor of PFL. Interestingly, BL21 expressing recombinant hydrogenase 1 did not produce detectable $\mathrm{H}_{2}$ following the addition of $10 \mathrm{mM}$ sodium hypophosphite (bar (c), Fig. 2). It was also mentioned that lack of $\mathrm{H}_{2}$ production ability in BL21 strain might be due to difference in activities of existing hydrogenases [25]. E. coli is known to use FHL pathway to produce $\mathrm{H}_{2}$ from formate. Nevertheless, we did not notice any meaningful $\mathrm{H}_{2}$ production in wild type BL21 even addition of formate while recombinant BL21 with expression of hydrogenase 


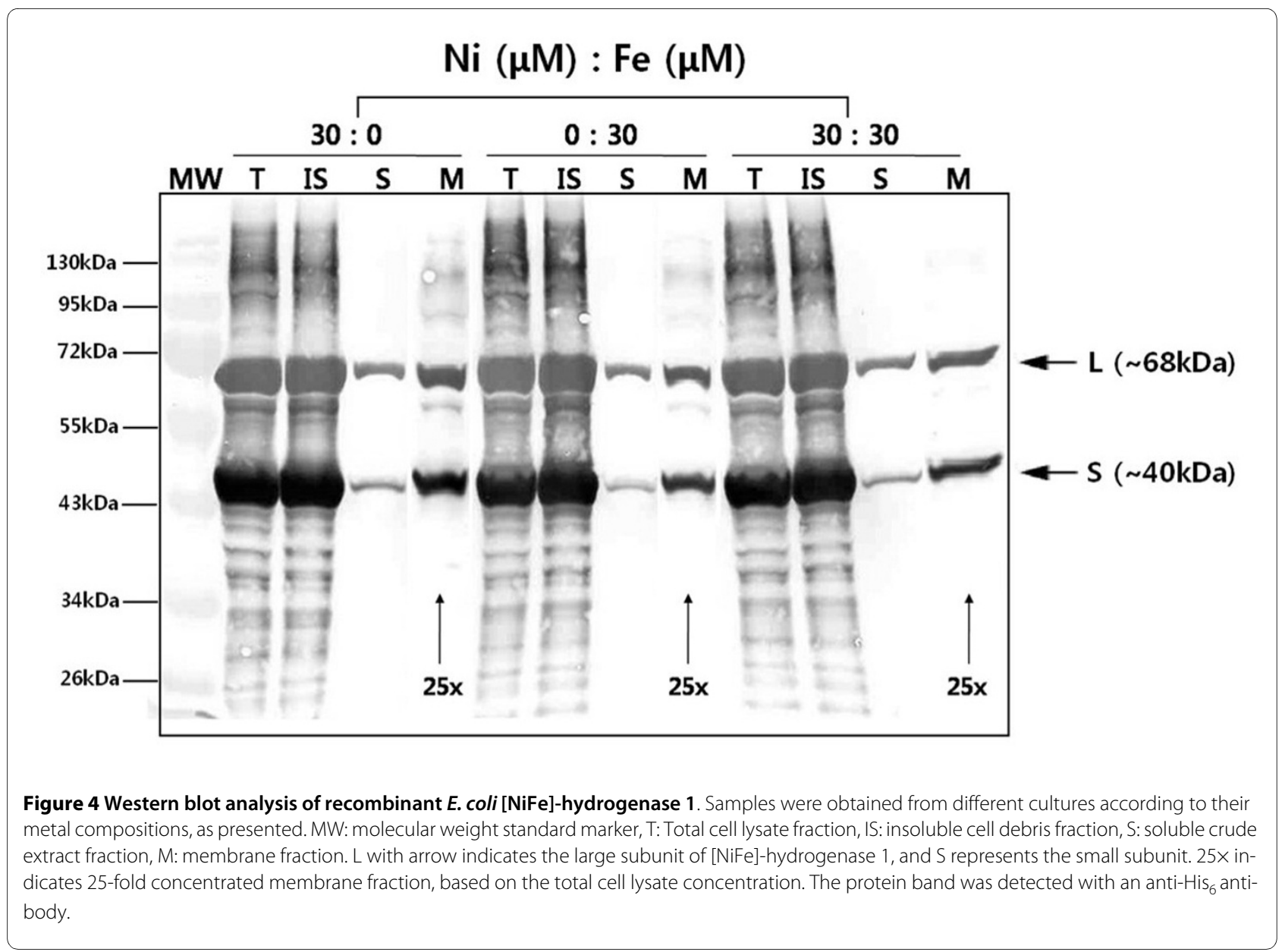

1 showed highly improved $\mathrm{H}_{2}$ production by exogenous formate. Therefore, we surmised this phenomenon strongly support possibility of impaired activity in FHL system. However, further investigation will be required on this point. As mentioned above, it was described that hydrogenase 1 content was also enhanced by exogenous formate even though it was not related to FHL activity and showed different global regulation [22]. Thus, these might be the reasons for improvement of $\mathrm{H}_{2}$ production in recombinant BL21 expressing hydrogenase 1. Collectively, these results support that $\mathrm{H}_{2}$ production in recombinant BL21, overexpressing hydrogenase 1, depend on function of recombinant hydrogenase 1 . Moreover, there have been no evidences or reports that function of hydrogenase 1 could activate FHL complex to produce hydrogen. In addition, formate is produced from pyruvate (the final product of glycolysis), we also checked the effect of glucose on $\mathrm{H}_{2}$ production by recombinant hydrogenase 1 for analysis of endogenous formate effect. However, we found that glucose had no noticeable effects on $\mathrm{H}_{2}$ production between concentrations of $0.5 \%$ and $1.5 \%(\mathrm{w} / \mathrm{v})$. It seems that there is regulation of internal formate synthesis and its concentration even if more investigation is required. From the results of glucose and sodium hypophosphite, it could be concluded that formate in vivo might has a crucial role for production of $\mathrm{H}_{2}$ by expression of recombinant hydrogenase 1 . We surmised that formate affects $\mathrm{H}_{2}$ production by recombinant hydrogenase 1 via triggering complex regulation of cellular mechanism and auxiliary proteins that require for hydrogenase function and expression [2]. Besides formate itself, $\mathrm{pH}$ change to acidic condition, caused by formate addition and according to culture time, might also influence on $\mathrm{H}_{2}$ production by recombinant hydrogenase 1 . We consider that more investigation is necessary related to cellular metabolism in future studies.

Since hydrogenase 1 contains nickel and iron at the active site [30], we investigated the effects of these metal ions on expression, in vivo $\mathrm{H}_{2}$ production, and in vitro enzyme activity (Fig. 3). Recombinant cells expressing $E$. coli hydrogenase 1 produced $\mathrm{H}_{2}$ most actively upon addition of both $\mathrm{Ni}$ and Fe. Cells also produced $\mathrm{H}_{2}$ in the sole presence of $\mathrm{Fe}$ or $\mathrm{Ni}$ in the medium at a lower level than those cultured with both metals, whereas there was no production of $\mathrm{H}_{2}$ without addition of both metals. This result could be interpreted that there is critical limit of $\mathrm{Ni}$ 
and Fe concentration required for function of recombinant hydrogenase 1 . This result also indicated that addition of $\mathrm{Ni}$ and $\mathrm{Fe}$ to the minimal media (with no detectable $\mathrm{Ni} \& \mathrm{Fe}$ ) have crucial impacts on the function and formation of recombinant hydrogenase 1 because [NiFe]-hydrogenase contains $\mathrm{Ni}$ and $\mathrm{Fe}$ at the active site in the large subunit and three [Fe-S] clusters with the role of electron transfer in the small subunit. We observed no significant differences in total protein expression upon alteration of metal content (Fig. 4), which might be due to the fact that anti-His ${ }_{6}$ antibody cannot differentiate apoenzyme with holoenzyme and unclear fractionation of recombinant hydrogenase due to overexpression. However, in vivo $\mathrm{H}_{2}$ production and in vitro enzyme activities were significantly affected according to metal addition. E. coli hydrogenase 1 exhibits relatively high ( $\sim 65 \%$ compared to total cell lysate) biological activity per unit protein mass in the membrane fraction even if the majority of $E$. coli hydrogenase 1 enzymes were expressed as insoluble forms and membrane translocation efficiency was very low (Fig. 4). Thus, this also implies that correctly translocated enzyme produces high quantity of $\mathrm{H}_{2}$ even with very small amount compared to total protein. $>$ From this study, membrane localization of [NiFe]hydrogenase is very important issue for exhibition of its innate ability. The low translocation efficiency problem should be solved to enhance $\mathrm{H}_{2}$ production in the recombinant $E$. coli system.

Importantly, E. coli [NiFe]-hydrogenase 1 maintains its biological activity during preparation of the cell extract or purification under a normal aerobic environment as described in Materials and Methods. Our experiments showed that the cell extract maintains in vitro $\mathrm{H}_{2}$ evolving activity over 10 days at $4^{\circ} \mathrm{C}$ under aerobic conditions (data not shown). This finding is in agreement with results from previous reports [5], demonstrating that [NiFe]-hydrogenase 1 has oxygen tolerance while [FeFe]hydrogenase is irreversibly inactivated by oxygen [25]. Accordingly, we propose that [NiFe]-hydrogenase 1 may be successfully used as an efficient biohydrogen production tool under aerobic or micro-aerobic conditions.

\section{Methods}

\section{Bacterial strains and culture conditions}

E. coli Top10 (F- mcrA $\Delta$ (mrr-hsdRMS-mcrBC) F80lacZDM15 AlacC74 recA1 araD139 $\Delta$ (ara-leu)7697 galU galK rpsL (Strr) endA1 nupG) (Invitrogen, USA) was used as the host strain for DNA manipulation and cloning of target genes. E. coli BL21 (DE3) (Novagen, USA) was used for recombinant expression of the hydrogenase gene. For genetic manipulation, LB medium (Difco, USA) containing the appropriate antibiotics $(50 \mu \mathrm{g} / \mathrm{mL}$ ampicillin) was employed. For protein expression, $1 \mathrm{mM}$ (final concentration) isopropyl- $\beta$-D-thiogalactopyranoside (IPTG; BioBasic, Canada) was added to each culture medium. For in vivo and in vitro $\mathrm{H}_{2}$ production, cells were grown in M9CA (6 g Na $2 \mathrm{HPO}_{4}, 3 \mathrm{~g} \mathrm{KH}_{2} \mathrm{PO}_{4}, 1 \mathrm{~g} \mathrm{NH}_{4} \mathrm{Cl}$, $0.5 \mathrm{~g} \mathrm{NaCl}, 5 \mathrm{~g}$ casamino acids, and $1 \mathrm{mg} / \mathrm{L}$ thiamine supplemented with $2 \mathrm{mM} \mathrm{MgSO} 4,0.1 \mathrm{mM} \mathrm{CaCl}$ ) medium including $0.5 \sim 1.5 \%(\mathrm{w} / \mathrm{v})$ glucose. All cultures were performed under normal aerobic or micro-aerobic conditions. Cells were grown in a serum bottle $(125$ or $500 \mathrm{~mL}$; Wheaton, USA) sealed with a rubber stopper and aluminum capping at $37^{\circ} \mathrm{C}$ in an air shaking incubator (Jeiotech, Korea) at a gyration rate of 200 230 rpm. For micro-aerobic condition, serum bottle containing medium (with empty head space, $20 \%$ of total bottle volume) was exposed to air for 5 min before seeding of cell stock and addition of IPTG. To determine the effects of metal (nickel or iron) on $\mathrm{H}_{2}$ production, $0.1 \mathrm{M} \mathrm{FeSO}_{4}$ and $1 \mathrm{M} \mathrm{NiSO}_{4}$ solutions were prepared, and the appropriate concentrations added to culture medium at the induction point as indicated. The metal concentrations of prepared M9CA before the addition of each metal solution were measured using an atomic absorption spectrometer (with the aid of the Korean Research Institute of Chemical Technology, Korea).

\section{Vector construction}

The E. coli K12 MG1655 genome as a template for gene amplification was extracted using the Wizard genomic DNA purification kit (Promega, USA). Primers were designed (upstream; 5'-AAGAGGTATATATTAATGAATAACGAGGAAACATTTTACCAGG-3', downstream; 5'-TTACGTCGGTGCAGCTTCGGCCAGCC ACTG-3') based on the sequence from the NCBI database to clone amplified full-length hya operon (from hyaA to hyaF) into pGEM-T vector (Promega). PCR reaction was performed using Taq polymerase (Takara, Japan) at following condition; 1 cycle of denaturation at $94^{\circ} \mathrm{C}$ for $5 \mathrm{~min}$ (genome)/1 $\mathrm{min} 40 \mathrm{sec}$ (plasmid template); 30 cycles of denaturation at $94^{\circ} \mathrm{C}$ for $2 \mathrm{~min}$ (genome) $/ 40 \mathrm{sec}$ (plasmid), annealing at $55^{\circ} \mathrm{C}$ for $40 \mathrm{sec}$ and extention at $72^{\circ} \mathrm{C}$ for time based on $1 \mathrm{~kb} / \mathrm{min} ; 1$ cycle of additional extention at $72^{\circ} \mathrm{C}$ for $5 \mathrm{~min}$. This vector was designated pGem-T/EcH3 (Fig. 1A). After sequencing, the full operon for hyaA-F was digested from pGem-T/EcH3 with EcoRI and cloned into pET 21b (Novagen). A DNA fragment containing hya $\mathrm{A}$ \&hya $\mathrm{B}$ genes was digested from the constructed vector with EcoRI and NsiI (located after the end of the hyaB open reading frame) and cloned between the EcoRI and PstI sites of pSE420 (Invitrogen). Finally, the fragment digested from the constructed vector using EcoRI and XhoI was cloned into pET-21b, and the construct denoted pET-EcHAB (Fig. 1B). Another expression vector, $\mathrm{pTrc}-\mathrm{EcH} 1 \mathrm{ABHis}$, based on $\mathrm{pTrcHisC}$ 
(Invitrogen), was generated for facile purification of recombinant hydrogenase 1 using the $\mathrm{His}_{6}$ affinity tag (Fig. 1C). $\mathrm{His}_{6}$-tag originally located in pTrcHis vector was fused to $\mathrm{N}$-terminal of large subunit (hyaB) and additional $\mathrm{His}_{6}$-tag for small subunit was fused to C-terminal of small subunit (hyaA) using PCR with primer containing $6 \times$ His sequence (CACCATCACCATCACCAC). Direction of $\mathrm{His}_{6}$-tag fusion was determined to avoid signal sequence of small subunit at $\mathrm{N}$-terminus and cleavage tail of large subunit at $\mathrm{C}$-terminus.

\section{Cellular fractionation}

Recombinant E. coli $(400 \mathrm{~mL})$ was harvested by centrifugation at $4{ }^{\circ} \mathrm{C}$ and $4,000 \mathrm{rpm}$ for $15 \mathrm{~min}$. The cell pellet was resuspended in $50 \mathrm{mM}$ Tris- $\mathrm{Cl}(\mathrm{pH}$ 6.8) and disrupted with a sonic dismembrator (Fisher scientific, USA) for $10 \mathrm{~min}$ at $50 \%$ power ( $5 \mathrm{sec}$ pulse on and $2 \mathrm{sec}$ pulse off). The disrupted cell suspension (total cell lysate fraction) was centrifuged at $4^{\circ} \mathrm{C}$ and $10,000 \mathrm{~g}$ for $20 \mathrm{~min}$. The resultant supernatant from previous centrifugation of total cell lysate (crude extract) was centrifuged again at $4^{\circ} \mathrm{C}$ and $120,000 \mathrm{~g}$ for $120 \mathrm{~min}$, and the pellet resuspended in $50 \mathrm{mM}$ Tris- $\mathrm{Cl}(\mathrm{pH} 6.8)$ with weak sonication at $4^{\circ} \mathrm{C}$ for a few seconds. This fraction was regarded as the crude membrane.

\section{Affinity purification}

After harvesting recombinant $E$. coli grown in M9CA, the cell pellet was resuspended in lysis buffer $(50 \mathrm{mM}$ $\mathrm{NaH}_{2} \mathrm{PO}_{4}, 300 \mathrm{mM} \mathrm{NaCl}, 10 \mathrm{mM}$ imidazole, $\mathrm{pH}$ 8.0) containing $1 \mathrm{mg} / \mathrm{mL}$ lysozyme (BioBasic), and incubated for $30 \mathrm{~min}$ on ice. After sonic disruption, Ni-NTA agarose slurry (Qiagen, Germany) was added to the cell lysate and mixed by gentle shaking on ice for $60 \mathrm{~min}$. The mixture was loaded on the chromatographic column. After NiNTA settled in the column, the resin was washed with buffer $\left(50 \mathrm{mM} \mathrm{NaH} \mathrm{PO}_{4}, 300 \mathrm{mM} \mathrm{NaCl}, 20 \mathrm{mM}\right.$ imidazole, $\mathrm{pH}$ 8.0) and bound $\mathrm{His}_{6}$-tagged protein to Ni-NTA resin eluted with buffer $\left(50 \mathrm{mM} \mathrm{NaH} \mathrm{PO}_{4}, 300 \mathrm{mM}\right.$ $\mathrm{NaCl}, 250 \mathrm{mM}$ imidazole, $\mathrm{pH}$ 8.0). The eluted sample was desalted by several ultrafiltration cycles using a Vivaspin column (MWCO 3,000; Sartorius, Germany) with $50 \mathrm{mM}$ Tris-Cl (pH 6.8) buffer. This desalted and concentrated sample was used later for in vitro $\mathrm{H}_{2}$ production enzyme activity assay. We performed all of procedures for purification and desalting under normal aerobic condition. In addition, the purified protein sample was analyzed by $15 \% \quad(\mathrm{w} / \mathrm{v}) \quad$ SDS-polyacrylamide gel electrophoresis (PAGE) and 10\% (w/v) native-PAGE. For SDS-PAGE, purified protein sample was resuspended in protein sample buffer (0.5 M Tris- $\mathrm{HCl}$ (pH6.8), 10\% glycerol; 5\% sodium dodecyl sulfate (SDS), $5 \% \beta$-mercaptoethanol, and $0.25 \%$ bromophenol blue) and heated to $100^{\circ} \mathrm{C}$ for 5 min. After centrifugation for $1 \mathrm{~min}$, the samples were loaded onto a $15 \%(\mathrm{w} / \mathrm{v})$ SDS-polyacrylamide gel for electrophoresis. For solubilization of the membrane fraction containing hydrogenase 1 in native-PAGE analysis, 15 $\mathrm{mM}$ n-octyl- $\beta$-D-thioglucoside (OTG; BioBasic) was added to the protein sample and incubated at $50^{\circ} \mathrm{C}$ for 20 $\mathrm{min}$. Electrophoresis was performed in $0.02 \mathrm{M}$ Tris/0.2 M glycine buffer ( $\mathrm{pH}$ 8.3). The gel was stained with Coomassie Brilliant Blue G-250 (Sigma) for SDS-PAGE and silver nitrate for native-PAGE (Sigma).

\section{Hydrogenase activity assay}

Hydrogenase activity was assayed via in vitro $\mathrm{H}_{2}$ evolution from MV (Sigma) reduced with sodium dithionite. In a $7 \mathrm{~mL}$ sealed vial, a $2.25 \mathrm{~mL}$ reaction mixture comprising $50 \mathrm{mM}$ Tris-Cl buffer (pH 6.8), $3 \mathrm{mM} \mathrm{MV}$ and prepared enzyme was purged with $\mathrm{N}_{2}$ gas for 3 min. The enzymatic reaction was initiated with the addition of $0.25 \mathrm{~mL}$ of sodium dithionite $(230 \mathrm{mM})$ at $37^{\circ} \mathrm{C}$ [31]. $\mathrm{H}_{2}$ evolution was measured every $5 \mathrm{~min}$ using a gas chromatograph (GC; Younglin Instrument, Korea) equipped with a carboxen-1010 PLOT column $(0.53 \mathrm{~mm} \times 30 \mathrm{~m}$; Supelco, USA) and pulsed discharge detector (Valco Instrument, USA). The gas sample $(100 \mu \mathrm{L})$ was obtained from the reaction vial and injected into GC. Elution was performed using helium as a carrier gas at a flow rate of 10 $\mathrm{mL} / \mathrm{min}$, and the temperatures of the injector, detector, and oven set to $130^{\circ} \mathrm{C}, 250^{\circ} \mathrm{C}$, and $100^{\circ} \mathrm{C}$, respectively. The $\mathrm{H}_{2}$ gas level was quantitatively estimated based on the linear relationship between the area of the $\mathrm{H}_{2}$ peak and amount of $1 \%$ standard $\mathrm{H}_{2}$ gas (Supelco).

\section{In vivo hydrogen production}

$\mathrm{H}_{2}$ gas produced in cell culture was obtained with a gastight syringe (Hamilton, USA) from the headspace of a serum bottle $(125$ or $500 \mathrm{~mL})$ sealed with a rubber stopper and aluminum cap. Usually, $20 \sim 100 \mu \mathrm{L}$ of the gas sample was analyzed using GC. The $\mathrm{H}_{2}$ concentration in the gas sample was calculated using a standard curve. The $\mathrm{H}_{2}$ amount was determined based on the $\mathrm{H}_{2}$ concentration and gas volume of headspace (which expanded when gas was extracted with a syringe).

\section{Page and Western blot analysis}

Samples for each strain with hydrogenase expression were prepared according to cellular fractionation, mixed with protein sample buffer $(0.5 \mathrm{M}$ Tris- $\mathrm{Cl}$ (pH 6.8), 10\% glycerol, $5 \%$ sodium dodecyl sulfate (SDS), $5 \% \beta$-mercaptoethanol, and $0.25 \%$ bromophenol blue), and heated to $100^{\circ} \mathrm{C}$ for $5 \mathrm{~min}$. After centrifugation for $1 \mathrm{~min}$, proteins were separated on a $15 \%$ gel. Following SDS-PAGE, gels were transferred to nitrocellulose membranes using a trans-blot cell (Hoefer, USA) and Bjerrum and Schafer- 
Nielsen transfer buffer ( $48 \mathrm{mM}$ Tris, $39 \mathrm{mM}$ glycine, and $20 \%$ methanol) for $1 \mathrm{~h}$ at $50 \mathrm{~V}$ and $50 \mathrm{~mA}$. Following transfer, membranes were immunoblotted with monoclonal anti-His ${ }_{6}$ antibody (Applied Biological Materials, Canada; 1:1000 dilution). For primary antibody detection, alkaline phosphatase-conjugated anti-mouse IgG (Sigma) was used as the secondary antibody. After immunoblotting, membranes were washed with TTBS and TBS and developed colorimetrically using nitro blue tetrazolium/ 5-bromo-4-chloro-3-indolyl phosphate (NBT/BCIP; Sigma).

\section{Competing interests}

The authors declare that they have no competing interests.

\section{Authors' contributions}

JYHK and HJC designed research. JYHK and BHJ performed and analyzed biohydrogen production in recombinant E. coli. JYHK and HJC wrote the paper. All authors have read and approved the final version of the manuscript.

\section{Acknowledgements}

This work was supported by the National Research Foundation of Korea Grant (NRF-2009-0093214) and the Brain Korea 21 Program funded by the Ministry of Education, Science and Technology, Korea and the Manpower Development Program for Marine Energy funded by the Ministry of Land, Transport and Maritime Affairs, Korea.

\section{Author Details}

'Department of Chemical Engineering, Pohang University of Science and Technology, Pohang 790-784, Korea and 2School of Interdisciplinary Bioscience and Bioengineering, Pohang University of Science and Technology, Pohang 790-784, Korea

Received: 7 May 2010 Accepted: 7 July 2010

Published: 7 July 2010

\section{References}

1. Stephen M, Stickland LH: Hydrogenase: a bacterial enzyme activating molecular hydrogen. Biochem J 1931, 25:205-214.

2. Vignais PM, Billoud B, Meyer J: Classification and phylogeny of hydrogenases. FEMS Microbiol Rev 2001, 25:455-501.

3. Bleijlevens B, Buhrke T, Van Der Linden E, Friedrich B, Albracht SPJ: The auxiliary protein HypX provides oxygen tolerance to the soluble [NiFe]hydrogenase of Ralstonia eutropha $\mathrm{H} 16$ by way of a cyanide ligand to nickel. J Biol Chem 2004, 279:46686-46691.

4. Frey M: Hydrogenases: hydrogen-activating enzymes. Chembiochem 2002, 3:153-160

5. Adams MW, Hall D: Purification of the membrane-bound hydrogenase of Escherichia coli. Biochem J 1979, 183:11-22.

6. Nishihara H, Miyashita Y, Aoyama K, Kodama T, Igarashi Y, Takamura Y: Characterization of an extremely thermophilic and oxygen-stable membrane-bound hydrogenase from a marine hydrogen-oxidizing bacterium Hydrogenovibrio marinus. Biochem Biophy Res Comm 1997, 232:766-770

7. Voordouw G: Evolution of hydrogenase genes. Adv Inorg Chem 1992 38:397-422.

8. Wu LF, Mandrand MA: Microbial hydrogenases: primary structure, classification, signatures and phylogeny. FEMS Microbiol Rev 1993, 104:243-270

9. Graf EG, Thauer RK: Hydrogenase from Methanobacterium thermoautotrophicum, a nickel-containing enzyme. FEBS Lett 1981, 136:165-169.

10. Self WT, Hasona A, Shanmugam KT: Expression and regulation of a silent operon, hyf, coding for hydrogenase 4 isoenzyme in Escherichia coli. J Bacteriol 2004, 186:580-587.

11. Menon NK, Chatelus CY, Dervartanian M, Wendt JC, Shanmugam KT, Peck $H D$, Przybyla AE: Cloning, sequencing, and mutational analysis of the hyb operon encoding Escherichia coli hydrogenase 2. J Bacterio/ 1994, 176:4416-4423.

12. Yoshida A, Nishimura T, Kawaguchi H, Inui M, Yukawa H: Enhanced hydrogen production from formic acid by formate hydrogen lyaseoverexpressing Escherichia coli strains. Appl Environ Microbiol 2005, 71:6762-6768.

13. Ballantine SP, Boxer DH: Isolation and characterisation of a soluble active fragment of hydrogenase isoenzyme 2 from the membranes of anaerobically grown Escherichia coli. Eur J Biochem 1986, 156:277-284.

14. Francis K, Patel P, Wendt JC, Shanmugam KT: Purification and characterization of two forms of hydrogenase isoenzyme 1 from Escherichia coli. J Bacteriol 1990, 172:5750-5757.

15. Menon NK, Robbins J, Wendt JC, Shanmugam KT, Przybyla AE: Mutational analysis and characterization of the Escherichia coli hya operon, which encodes [NiFe] hydrogenase 1. J Bacterio/ 1991, 173:4851-4861.

16. Sawers RG, Boxer DH: Purification and properties of membrane-bound hydrogenase isoenzyme 1 from anaerobically grown Escherichia coli K12. Eur J Biochem 1986, 156:265-275.

17. Sanchez-Torres V, Maeda T, Wood TK: Metabolic engineering to enhance bacterial hydrogen production. Microbial Biotechnol 2008, 1:30-39.

18. Redwood MD, Mikheenko IP, Sargent F, Macaskie LE: Dissecting the roles of Escherichia coli hydrogenases in biohydrogen production. FEMS Microbiol Lett 2008, 278:48-55.

19. King PW, Przybyla AE: Response of hya expression to external pH in Escherichia coli. J Bacteriol 1999, 181:5250-5256.

20. Laurinavichene TV, Tsygankov AA: $\mathrm{H}_{2}$ consumption by Escherichia coli coupled via hydrogenase 1 or hydrogenase 2 to different terminal electron acceptors. FEMS Microbiol Lett 2001, 202:121-124.

21. Richard DJ, Sawers G, Sargent F, McWalter L, Boxer DH: Transcriptiona regulation in response to oxygen and nitrate of the operons encoding the [NiFe] hydrogenases 1 and 2 of Escherichia coli. Microbiology 1999, 145:2903-2912.

22. Sawers RG, Balantine SP, Boxer DH: Differential expression of hydrogenase isoenzymes in Escherichia coli K-12: evidence for a third isoenzyme. J Bacteriol 1985, 164:1324-1331.

23. Kim JYH, Jung HJ, Cha HJ: Universal degenerate oligonucleotideprimed-polymerase chain reaction for detection and amplification of NiFe-hydrogenase genes. Enzyme Microb Technol 2007, 42:1-5.

24. Hayes ET, Wilks JC, Sanfilippo P, Yohannes E, Tate DP, Jones BD, Radmacher MD, BonDurant SS, Slonczewski JL: Oxygen limitation modulates $\mathrm{pH}$ regulation of catabolism and hydrogenase, multidrug transporters, and envelope composition in Escherichia coli K-12. BMC Microbiol 2006, 6:89

25. Akhtar MK, Jones PR: Deletion of iscR stimulates recombinant clostridial Fe-Fe hydrogenase activity and $\mathrm{H}_{2}$-accumulation in Escherichia coli BL21 (DE3). App/ Microbiol Biotechnol 2008, 78:853-862.

26. Laurinavichene TV, Zorin NA, Tsygankov AA: Effect of redox potential on activity of hydrogenase 1 and hydrogenase 2 in Escherichia coli. Arch Microbio/ 2002, 178:437-442

27. Rossmann R, Sauter M, Lottspeich F, Bock A: Maturation of the large subunit (HYCE) of Escherichia coli hydrogenase 3 requires nickel incorporation followed by C-terminal processing at Arg537. Eur $J$ Biochem 1994, 220:377-384

28. Mishra J, Khurana S, Kumar N, Ghosh AK, Das D: Molecular cloning, characterization, and overexpression of a novel [Fe]-hydrogenase isolated from a high rate of hydrogen producing Enterobacter cloacae IIT-BT 08. Biochem Biophy Res Comm 2004, 324:679-685.

29. Sawers RG: Formate and its role in hydrogen production in Escherichia coli. Biochem Soc Trans 2005, 33:42-46.

30. Volbeda A, Charon MH, Piras C, Hatchikian EC, Frey M, Fontecilla-Camps $J C$ : Crystal structure of the nickel-iron hydrogenase from Desulfovibrio gigas. Nature 1995, 373:580-587.

31. Tamiya N, Kondo Y, Kameyama T, Akabori S: Determination of hydrogenase by the hydrogen evolution from reduced methyl viologen. J Biochem 1955, 42:613-614.

doi: 10.1186/1475-2859-9-54

Cite this article as: Kim et al., Production of biohydrogen by recombinant expression of [NiFe]-hydrogenase 1 in Escherichia coli Microbial Cell Factories $2010,9: 54$ 